\title{
Food sovereignty: Reality vs. assumptions
}

\author{
Review by Cassandra Hawkins Wilder* \\ Alcorn State University
}

Review of $W e W$ ant Land to Live: Making Political Space for Food Sovereignty, by Amy Trauger. (2017). Published by University of Georgia Press. Available as hardcover, paperback and ebook; 172 pages. Publisher's website: http://www.ugapress.org/index.php/books/we _want land to live

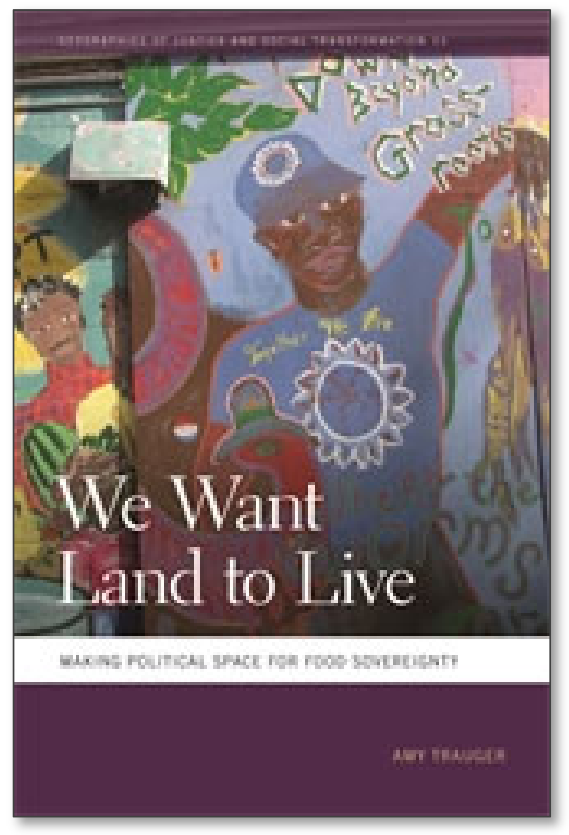

Submitted July 12, 2017 / Published online September 5, 2017

Citation: Wilder, C. H. (2017). Food sovereignty: Reality vs. assumptions [Book review]. Journal of Agriculture, Food Systems, and Community Development, 7(3), 223-224. http://dx.doi.org/10.5304/jafscd.2017.073.015

Copyright (C) 2017 by New Leaf Associates, Inc.

$\mathrm{I}^{\mathrm{n}}$ W $W$ ant Land to Live, author Amy Trauger endeavors to draw attention to food sovereignty, its practices, and its political implications. Written during a time where the discussion of

\footnotetext{
* Cassandra Hawkins Wilder is a policy research analyst for the Socially Disadvantaged Farmers and Ranchers Policy Research Center, located at Alcorn State University in Lorman, Mississippi, where she focuses her research efforts on addressing issues and challenges that affect socially disadvantaged farmers and ranchers. As a daughter of farmers, Cassandra is passionate about transforming anecdotal stories into research data, which she hopes will lead to policy recommendations. Cassandra is currently a doctoral candidate in the Public Administration program at Jackson State University. Her concentration is policy analysis. In her free time, Cassandra loves to doodle in her bullet journal, devour books of all genres, and spend time with her family. She can be reached at chwilder@alcorn.edu.
}

hunger and poverty in a global context is a top priority, We Want Land to Live presents a convincing argument for understanding how food sovereignty interacts with not only global political systems but international economic and social systems as well.

Trauger has an impressive background that includes experience as a feminist geographer with substantial experience in farming. In the introduction, Trauger presents a synopsis of her childhood as well as her current farming experience in Georgia. She details chronologically the personal experiences that have contributed to her interest in the episteme of food sovereignty, to which she dedicates an entire chapter. Through this window into Trauger's personal life, the reader is able to resonate with the passion that jumps from each 
page. Trauger's writing style is both open and scholarly, while providing a clear argument from a critical perspective about food sovereignty.

In $W e W$ ant Land to Live, Trauger ventures to address a gap in the food sovereignty literature that addresses the presence of political implications. She presents a very compelling case to examine food sovereignty and its impact on "the transformation of meaning, primarily around land, labor, and exchange" (p. 30). The book leaves a memorable impression of all the stakeholders and major players involved in the food system and food security throughout the world. Utilizing the book as a possible platform to highlight those unique threats that emerge from food sovereignty, Trauger offers a sophisticated theoretical perspective about the role of food sovereignty "as a radical and collective struggle for alternative political spaces” (p. 12). Trauger's knowledge of the policies surrounding food sovereignty is evident and articulated in a detailed fashion within the text.

Using ethnographic methods to assemble data for her research, Trauger concentrates specifically on explaining the production of spaces by food sovereignty, the mobilization of power within these identified spaces, and the definition of food sovereignty. For example, in her chapter on urban agriculture, Trauger gives an illustration of the privatization of urban land and its correlation to food sovereignty. According to Trauger, these cases adequately reveal the necessity of an "alternative mode of governance" (p. 63). Trauger structures her argument to call for an ideological shift regarding food sovereignty through the case studies presented in the book.

Trauger claims further that capitalism fuels the presence of federalism and prevents the recognition of the rights of local communities. She implies that "reterritorializing of power" (p. 80) should be a direct result of the shift in governance from the alternative spaces being created by food sovereignty.

This book recognizes the relationship between the assumptions and reality surrounding food sovereignty. Individuals interested in different perspectives to food sovereignty and its implications will value this book. Readers can benefit from Trauger's theories and plausible strategies to approach the various spaces that are generated by food sovereignty. Her critical perspective encourages future research into food sovereignty and the spaces being created by it. 